\title{
温熱環境評価のための人体熱数值計算モデル COM の開発 DEVELOPMENT OF NUMERICAL THERMOREGULATION-MODEL COM FOR EVALUATION OF THERMAL ENVIRONMENT
}

\author{
田辺新一*, 小林弘造**, 小川一晃*** \\ Shin-ichi TANABE, Kozo KOBAYASHI and Kazuaki OGAWA
}

\begin{abstract}
The human thermoregulation model COM (Complex Thermal Environment Comfort Model) was developed, incorporating the blood flow model for extremities and the conductive heat transfer model at contacting skin surfaces. The whole body model has 17 body segments, each consisting of 2 compartments for core and skin. Each core compartment of extremities has artery and vein blood pool in its center. The central blood compartment exchanges heat with blood pools and the tissues except extremities. The heat balance equations for each tissue are described. The current model is able to predict fairly well for the body temperature distribution under unsteady state conditions.
\end{abstract}

Keywords : Thermal comfort, Numerical model, Blood flow of extremities, Counter-current heat exchange 熱的快適性，数値計算，四肢血流，对向流熱交換

\section{1.はじめに}

過去の温熱環境指標に関する研究の中で広く使用されてきた PMV (Predicted Mean Vote) ${ }^{1}$ 及び SET* (Standard New Effec-

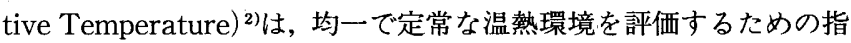
標である。しかし，実際の温熱環境は不均一かつ非定常である場合 が多く，そのような環境の評価が望まれている。

我々の研究グループは，非定常・不均一な温熱環境の評価を目的 として人体熱数值計算モデル $65 \mathrm{MN}^{3 / 4)}$ および $3 \mathrm{DM}^{5 / 6)}$ の開発を行っ てきた。65MN は，血管系の簡易なモデル化等により，寒冷環境下 で数值解析の結果が実際の人間の皮膚温分布から外れてしまうケー スがあった。一方，血管系および呼吸器系等を詳細に取り扱ってい る3DM では, 詳細モデルの作成のために膨大なデータの取得が必要 となるため，人体熱モデルによる解析には目的に応じた使い分けが 必要である。

本研究では，実在温熱環境の評洒への適用が容易で，精度良く皮 膚温分布を予測可能な人体熱数值計算モデル COM (Complex Thermal Environment Comfort Model) を開発した。COM は, 詳細な四肢血流モデルを含み, 人体を Core 層と Skin 層からなる17 の Segment に分割しモデル化している。人体 Segment 別の温熱環 境 6 要素を境界条件として入力することによって, 不均一かつ非定 常状態にある温熱環境に曝露された人間の生理量・心理量を予測す る。本論文では, COMの概要と, 被験者実験との比較によりその予 測精度を示す。

\section{2. 被制御系のモデル}

\section{2-1 人体の分割}

本モデルの人体は，Stolwijk のモデルの体型を参考として設定し た。この体型は, SET*で想定される体型にも近く, $65 \mathrm{MN}$ との比較 を容易とするため使用した。日本人の体型より大きく設定されてい るが，比較を行った被験者実験の体型ともほぼ一致している。人体 のモデルは, 図 1 に示すように全身を17の Segment に分割するもの

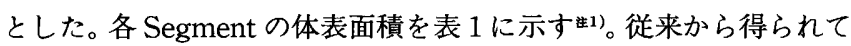
いる生理量および熱物性値デー夕を利用できるように, 各 Segment は Core 層とSkin 層の 2 層に分割するものとした。同 Segment の Core 層と Skin 層は熱伝導により熱交換を行い, Skin 層は外部環境 と, 対流，放射，蒸発，熱伝導により熱交換を行う。また，呼吸に よる熱損失が Chest の Core 層で考虑される。四肢の12の Segment においては, Core 層の中心に Arterial FlowとVenous Flow を置 き，血流を介しての熱交換が行われる。図2に四肢のモデル概念図 を示す。四肢を除く Segment の血流輸送による熱交換は, Central Blood Flow との熱交換として簡易にモデル化した。

\section{2-2 血流のモデル化方法}

四肢を除く Segment での熱交換を図 3 に示す。四肢 Segment 以 外では Stolwijkのモデル7)8)を採用している。各 Segment の Core 層およびSkin 層はそれぞれ Central Blood Flowとの熱交換を行 う。すなわち, 主要な生体内熱移動経路である血流循環による熱移 動は, Central Blood Flow を介しての Segment 間の熱交換として モデル化される。この Central Blood Flowとは，心臟および四肢 を除く Segment の動静脈の血管系および血液を指すものである。
* 早稲田大学理工学部建築学科 教授.工博

***侏)日建設計設備設計部 工修

***秼日本ERI ソリューション事業部 工修
Prof., Dept. of Architecture, Waseda University, Dr. Eng.

Nikken Sekkei Co., Ltd., M. Eng.

Japan ERI Co., Ltd., M. Eng. 


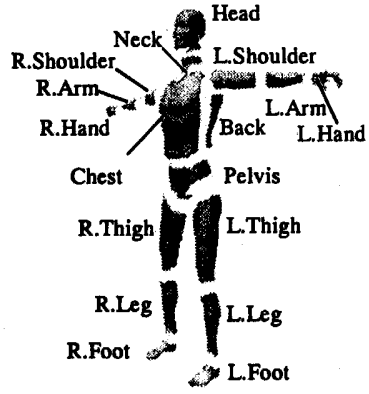

图 1 Segment 分割

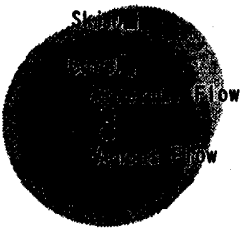

図 2 四肢 Segment のモデル

しかし，四肢 Segmentにおいては，各層に流入する動脈血温度を 全身一様と仮定するStolwijk のモデルは精度よい解析結果を与え ないことがある。特に寒冷環境や極めて不均一な温熱環境下で精度 良く体内温度分布を予測するためには，動脈血温度分布を精度良く 予測できる血流循環のモデル化が必要となる99。

そこで, 四肢 Segment については, 各 Segment の Core 層の中心 に動脈を表す Arterial Flow と静脈を表す Venous Flow 配した モデルを作成した㳯2）図 4 に四肢 Segment での熱交換を示す。Arterial Flow は血流の前 Segmentの Arterial Flow から血液が流入 し, 完全混合の後, 一部は同 Segment の Core 層および Skin 層へ, 残りは次 Segment の Arterial Flowに流出する。また, Venous Flow は同 Segment の Core 層およびSkin 層と, 血流の前 Segment の Venous Flow から血液が流入し, 完全混合の後, 次 Segment の Venous Flow に流出する。Arterial/Venous Flow と Core 層との熱交換として，血管系と周囲組織との熱交換が考慮される。 また，Arterial Flow と Venous Flow との熱交換として，血管系同 士の対向流熱交換13)を考慮した。

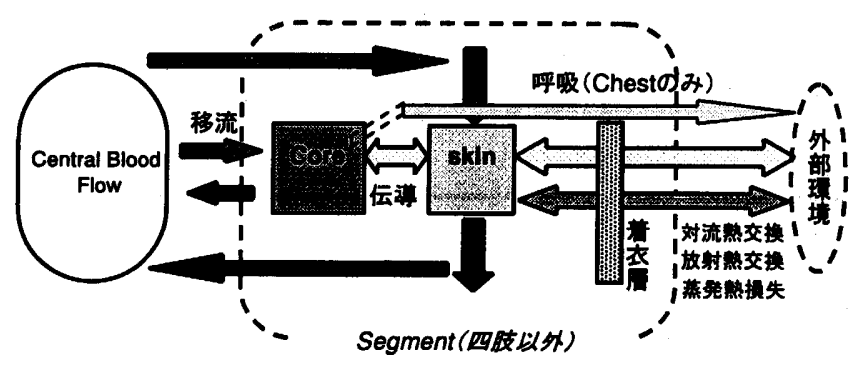

図 3 四肢を除くSegment での熱交換

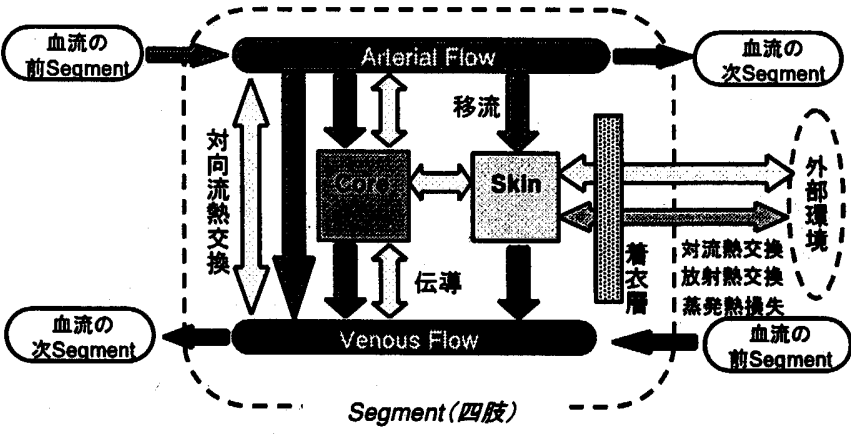

図 4 四肢 Segment での熱交換

\section{3. 各部の熱平衡式}

各部の熱平衡式は(1)〜(5)式のように表される"33)法4。熱平衡式中の 記号は表 2 に示し, 各々の項に関しては3-1以降に述べる。生体内の 個々の生理量および熱物性值は, 文献7）１3）を参考に分割した人体 各部に与えた。

- Core 層の熱平衡式

$$
\begin{aligned}
C_{c r} \frac{d T_{c r}}{d t}= & M_{c r}+\rho c V_{c r}\left(T_{a r}-T_{c r}\right)-K\left(T_{c r}-T_{s k}\right) \\
& +K_{V}\left(T_{a r}-T_{c r}\right)+K_{V}\left(T_{v e}-T_{c r}\right)-Q_{r e s}
\end{aligned}
$$

- Skin 層の熱平衡式

$$
\begin{aligned}
C_{s k} \frac{d T_{s k}}{d t}= & M_{s k}+\rho c V_{s k}\left(T_{a r}-T_{s k}\right)+K\left(T_{c r}-T_{s k}\right) \\
& -Q_{m t}-E_{s k}-Q_{t} \ldots \ldots \ldots \ldots \ldots \ldots \ldots \ldots \ldots \ldots \ldots \ldots \ldots \ldots \ldots \ldots \ldots \ldots
\end{aligned}
$$

• Arterial Flow の熱平衡式

$$
\begin{aligned}
C_{a r} \frac{d T_{a r}}{d t}= & \rho c V_{a r^{*}}\left(T_{a r^{*}}-T_{a r}\right)-K_{V}\left(T_{a r}-T_{c r}\right) \\
& -K_{A V}\left(T_{a r}-T_{v e}\right) \quad \ldots \ldots \ldots \ldots \ldots \ldots \ldots \ldots \ldots \ldots \ldots \ldots \ldots \ldots \ldots \ldots
\end{aligned}
$$

\begin{tabular}{|c|c|c|}
\hline$C[k J / K]$ & \multicolumn{2}{|l|}{ 㙰容是 } \\
\hline$E_{\text {ek }}[W]$ & \multicolumn{2}{|l|}{ 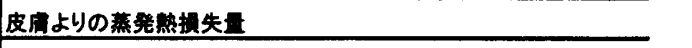 } \\
\hline$K\left[W /{ }^{\circ} C\right]$ & \multicolumn{2}{|c|}{ 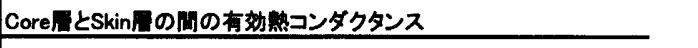 } \\
\hline$K_{A V}\left[W /{ }^{\circ} \mathrm{C}\right]$ & \multicolumn{2}{|c|}{ Arterial FlowとVenous Flowの閏の有効整コンダクタンス } \\
\hline$K_{V}\left[W /{ }^{\circ} C\right]$ & \multicolumn{2}{|c|}{ 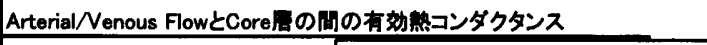 } \\
\hline$M[W]$ & 㦃整量 & \multirow{3}{*}{$\begin{array}{l}\text { 以下添字 } \\
\text { ar Arterial Flow } \\
\text { ar* 血流の前SegmentのArterial Flow }\end{array}$} \\
\hline$Q_{\text {res }}[W]$ & 呼吸による整損失量 & \\
\hline$Q,[W]$ & 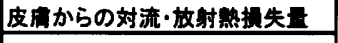 & \\
\hline$t[h]$ & 時问 & \multirow{4}{*}{ 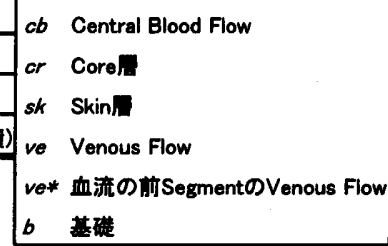 } \\
\hline$T\left[^{\circ} \mathrm{C}\right]$ & 温度 & \\
\hline$V[L / h]$ & 血流早 & \\
\hline$\rho c[k J / L K]$ & 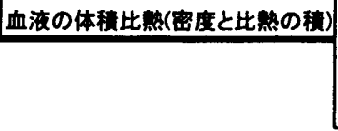 & \\
\hline
\end{tabular}

• Venous Flow の熱平衡式

$$
\begin{aligned}
C_{v e} \frac{d T_{v e}}{d t}= & \rho c V_{c r}\left(T_{c r}-T_{v e}\right)+\rho c V_{s k}\left(T_{s k}-T_{v e}\right) \\
& +\rho c V_{v e^{*}}\left(T_{v e^{*}}-T_{v e}\right) \\
& -K_{V}\left(T_{v e}-T_{c r}\right)+K_{A V}\left(T_{a r}-T_{v e}\right)
\end{aligned}
$$

表 2 記号一覧 
- Central Blood Flow の熱平衡式

$$
\begin{aligned}
& C_{c b} \frac{d T_{c b}}{d t}=\sum_{\text {四肢を除 }} \sum_{\text {各Segment }}\left\{\rho c V_{c r}\left(T_{c r}-T_{c b}\right)\right.
\end{aligned}
$$

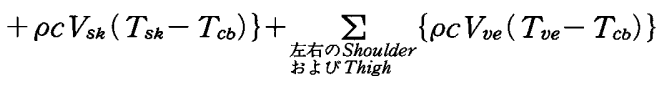

\section{3-1 熱容量}

$C\left[\mathrm{Wh} /{ }^{\circ} \mathrm{C}\right]$ は各部の熱容量, $T\left[{ }^{\circ} \mathrm{C}\right]$ は温度を表す。表 3 に計 算に用いた各部の熱容量を示す。この熱容量は, 各組織の比熱を骨 $2.088 \mathrm{~kJ} / \mathrm{kgK}$, 皮下脂肪 $2.506 \mathrm{~kJ} / \mathrm{kgK}$ ，その他 $3.758 \mathrm{~kJ} / \mathrm{kgK}$, 血液 の体積比熱を $4.186 \mathrm{~kJ} / \mathrm{LK}$ として算出した。各 Segment の Arterial/Venouse Flow の熱容量はその Segment の Core 層から, Central Blood Flow の熱容量は Chest およびBackの Core 層から均 等に差し引いた。

表 3 各部の熱容量 $[\mathrm{kJ} / \mathrm{K}]$

\begin{tabular}{l|r|r|r|r|}
\hline Segment & Core & Skin & Arterial Flow Venous Flow \\
\hline \hline Head & 9.140 & 0.792 & & \\
\hline Neck & 2.426 & 0.209 & & \\
\hline Chest & 34.246 & 1.588 & & \\
\hline Back & 30.837 & 1.462 & & \\
\hline Pelvis & 53.752 & 2.002 & & 0.256 \\
\hline L.Shoulder & 6.028 & 0.544 & 0.067 & 0.140 \\
\hline L.Arm & 3.981 & 0.356 & 0.033 & 0.075 \\
\hline L.Hand & 0.514 & 0.356 & 0.016 & 0.256 \\
\hline R.Shoulder & 6.028 & 0.544 & 0.067 & 0.0 .140 \\
\hline R.Arm & 3.981 & 0.356 & 0.033 & 0.140 \\
\hline R.Hand & 0.514 & 0.356 & 0.016 & 0.075 \\
\hline L.Thigh & 18.858 & 1.469 & 0.293 & 1.009 \\
\hline L.Leg & 10.146 & 0.788 & 0.144 & 0.536 \\
\hline L.Foot & 0.680 & 0.461 & 0.037 & 0.161 \\
\hline R.Thigh & 18.858 & 1.469 & 0.293 & 1.009 \\
\hline R.Leg & 10.146 & 0.788 & 0.144 & 0.536 \\
\hline R.Foot & 0.680 & 0.461 & 0.037 & 0.161 \\
\hline Central Blood Flow & & & & 16.762 \\
\hline
\end{tabular}

\section{3-2 産熱量}

$M_{c r}[\mathrm{~W}], M_{s k}[\mathrm{~W}]$ はそれぞれ各 Segment の Core 層, Skin 層 における産熱量であり，(6)式で表現される。 $M_{b}[\mathrm{~W}], W[\mathrm{~W}], M_{\text {shiv }}$ [W] はそれぞれ各 Segment の基礎代謝量, 外部仕事による熱産生 量, 子る之熱産生量である゙5)。表 4 に各部の基礎代謝量を示す。外

表 4 各部の基礎代謝量 [W] とMetf 值

\begin{tabular}{l|r|r|r}
\hline Segment & Core & Skin & \\
\hline Head & 16.896 & 0.104 & 0.000 \\
\hline Neck & 0.274 & 0.028 & 0.000 \\
\hline Chest & 24.287 & 0.179 & 0.091 \\
\hline Back & 21.737 & 0.158 & 0.080 \\
\hline Pelvis & 12.921 & 0.254 & 0.129 \\
\hline L.Shoulder & 1.215 & 0.050 & 0.026 \\
\hline L.Arm & 0.346 & 0.026 & 0.014 \\
\hline L.Hand & 0.090 & 0.050 & 0.005 \\
\hline R.Shoulder & 1.215 & 0.050 & 0.026 \\
\hline R.Arm & 0.346 & 0.026 & 0.014 \\
\hline R.Hand & 0.090 & 0.050 & 0.005 \\
\hline L.Thigh & 1.318 & 0.122 & 0.201 \\
\hline L.Leg & 0.357 & 0.023 & 0.099 \\
\hline L.Foot & 0.212 & 0.100 & 0.005 \\
\hline R.Thigh & 1.318 & 0.122 & 0.201 \\
\hline R.Leg & 0.357 & 0.023 & 0.099 \\
\hline R.Foot & 0.212 & 0.100 & 0.005 \\
\hline Total & & 8.656 & 1.000 \\
\hline
\end{tabular}

部仕事とふるえによる熱産生は Core 層でのみ発生するものとし た。

$$
\begin{array}{ll}
M_{c r}=M_{b, c r}+W+M_{\text {shiv }} & M_{s k}=M_{b, s k} \\
W=58.2\left(m e t-M_{b, \text { total }}\right) & A_{\text {Du,total }} \text { Metf }
\end{array}
$$

式(7)の met [met] は活動の種類により推定される全身の代謝量, $M_{b, t o t a l}$ [met] は全身の基礎代謝量, $A_{D u, t o t a l}\left[\mathrm{~m}^{2}\right]$ は全身の体表面 積である。 $M_{b, t o t a l}$ は表 4 に示した各部の基礎代謝量の合計から得ら れ本研究では0.778metとなる。met がこれを下回ることはないと した。すなわち，Wが負値となる場合は 0 とする。Metf $[$ 一 $]$ は仕 事熱産生についての各 Segment 筋肉層の全身に对する相対比であ る。これを表 4 に示す。ふるえ熱産生量 $M_{\text {shiv }}$ の算出式については後 述する。

\section{3-3 血液による熱輸送}

(1)式右辺第 2 項および(2)式右辺第 2 項は，血流によって組織へ輸 送される熱量を表す。 $T_{a r}$ と表記される動脈血温度は，四肢を除く Segment では Central Blood Flow 温度と考える。本モデルでは, 移流による熱移動については，流入する動脈血液と組織の熱交換が 完全に行われるという仮定をした。 $V[\mathrm{~L} / \mathrm{h}]$ は各部の血流量, $\rho C$ $[\mathrm{kJ} / \mathrm{LK}]$ は血液の体積比熱（密度と比熱の積）である。本モデルで は=4.186kJ/LKとした。(8)式はCore 層の血流量を表す。 $V_{b}[\mathrm{~L} / \mathrm{h}]$ は基礎血流量であり表 5 に本計算で用いた値を示す。Core 層の血流 量増加は産熱量増加に依存すると考えている。すなわち, $3,600 \mathrm{~kJ} の$ 産熱のために，0.860Lの血流が必要であるという仮定をした勇8。

$$
V_{c r}=V_{b, c r}+0.860\left(W+M_{\text {shiv }}\right)
$$

(3)式右辺第 1 項および(4)式右辺第 3 項は，血流により前 Segment から輸送される熱量を表す。 $T_{a r}$ と表記される血流の前 Segment の動脈血温度は，躯幹部から四肢への血液流入点となる Shoulder およびThighのArterial Flowの熱平衡式においてはCentral Blood Flow 温度と考える。また, Shoulder およびThigh の静脈血 は，(5)式に示されるようにCentral Blood Flowに熱を輸送する。 こうして, 四肢血流は Centeral Blood Flowを起点として往復す る。

表 5 各部の基礎血流量 $[\mathrm{L} / \mathrm{h}]$

\begin{tabular}{l|r|r}
\hline Segment & Core & Skin \\
\hline Head & 32.228 & 5.725 \\
\hline Neck & 15.240 & 0.325 \\
\hline Chest & 89.214 & 1.967 \\
\hline Back & 87.663 & 1.475 \\
\hline Pelvis & 33.518 & 2.272 \\
\hline L.Shoulder & 1.808 & 0.910 \\
\hline L.Arm & 0.940 & 0.508 \\
\hline L.Hand & 0.217 & 1.114 \\
\hline R.Shoulder & 1.808 & 0.910 \\
\hline R.Arm & 0.940 & 0.508 \\
\hline R.Hand & 0.217 & 1.114 \\
\hline L.Thigh & 1.406 & 1.456 \\
\hline L.Leg & 0.164 & 0.651 \\
\hline L.Foot & 0.080 & 0.934 \\
\hline R.Thigh & 1.406 & 1.456 \\
\hline R.Leg & 0.164 & 0.651 \\
\hline R.Foot & 0.080 & 0.934 \\
\hline Total & & 290.003 \\
\hline
\end{tabular}

\section{3-4＼cjkstart組織間の伝導による熱交換}

(1)式右辺第 3 項および(2)式右辺第 3 項は, Core 層と Skin 層との 間の伝導による熱交換を表す。Core 層と Skin 層との間には，筋肉 
表 6 各 Node 間の熱コンダクタンス $\left[\mathrm{W} /{ }^{\circ} \mathrm{C}\right]$

\begin{tabular}{l|r|l|l}
\hline Segment & Core-Skin & $\begin{array}{l}\text { Core } \\
\text {-Arterial Nenous Flow }\end{array}$ & $\begin{array}{l}\text { Arterial Flow } \\
- \text { Venous Flow }\end{array}$ \\
\hline \hline Head & 3.422 & & \\
\hline Neck & 0.909 & & \\
\hline Chest & 1.782 & & \\
\hline Back & 1.640 & & \\
\hline Pelvis & 2.247 & & \\
\hline L.Shoulder & 1.501 & 0.586 & 0.537 \\
\hline L.Arm & 0.982 & 0.383 & 0.351 \\
\hline L.Hand & 2.183 & 1.534 & 0.762 \\
\hline R.Shoulder & 1.501 & 0.586 & 0.537 \\
\hline R.Arm & 0.982 & 0.383 & 0.351 \\
\hline R.Hand & 2.183 & 1.534 & 0.762 \\
\hline L.Thigh & 2.468 & 0.810 & 0.826 \\
\hline L.Leg & 1.326 & 0.435 & 0.444 \\
\hline L.Foot & 3.370 & 1.816 & 0.992 \\
\hline R.Thigh & 2.468 & 0.810 & 0.826 \\
\hline R.Leg & 1.326 & 0.435 & 0.444 \\
\hline R.Foot & 3.370 & 1.816 & 0.992 \\
\hline
\end{tabular}

内側表面から脂肪を通り皮膚までの熱コンダクタンスが与えられ た ${ }^{14)}$ 。(1)式右辺第 4 項および第 5 項は Core 層と Arterial/Venous Flow との熱交換を表し，COM では四肢 Segmentのみで考虑する ものとして四肢を除く Segment では值を持たないものとした。(3)式 右辺第 3 項および(4)式右辺第 5 項は，血管系同士の対向流熱交換を 表す。表 6 に計算に用いた各 Node 間の熱コンダクタンスを示す。

\section{3-5 呼吸による熱損失}

呼吸による熱損失 $Q_{\text {res }}$ は Chest の Core 層のみで発生すること とした\#6)。Qres は(9)式で表される。

$Q_{\text {res }}=58.2$ met $\left(0.0014\left(34-t_{a, \text { head }}\right)\right.$

$$
+0.0173\left(5.87-p_{a, \text { head }}\right) A_{\text {Du,total }} \text {. }
$$

$t_{a, \text { head }}\left[{ }^{\circ} \mathrm{C}\right], p_{a, \text { head }}[\mathrm{kPa}]$ はそれぞれ Head での空気温度，水蒸 気圧である。

\section{3-6 蒸発熱損失}

(2)式の $E_{s k}[\mathrm{~W}] は$ 各 Segment の Skin 層における蒸発熱損失量て あり，(10)式のように表現される。 $E_{\text {dif }}[\mathrm{W}]$ は各 Segment の不感蒸 泄による熱損失量であり，(11)式で示される。また， $E_{s w}[\mathrm{~W}]$ は各 Segment の発汗による蒸発熱損失量である。

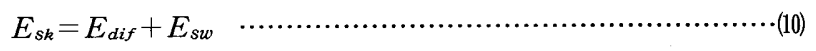

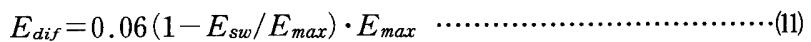

ここで, $E_{\max }[\mathrm{W}]$ は各部位の最大蒸発熱損失量であり，(12)式か ら求められる。Stolwijk モデル7)8)では, 不感蒸泄に関しては定数を 与えているが，この值は $E_{\max }$ の 3 〜 \%に相当する值となってい る。本モデルでは, 各部位の不感蒸泄を, 発汗の無い面積率につい ての最大蒸発熱損失量の $6 \%$ として計算を行っている ${ }^{15)}$

$E_{\max }=h_{e}\left(p_{s, s k}-p_{a}\right) A_{D u}$ $\cdot(12)$

ここで, $h_{e}\left[\mathrm{~W} / \mathrm{m}^{2} \mathrm{kPa}\right]$ は各部位の皮膚表面から環境までの潜熱 伝達率， $p_{s, s k}[\mathrm{kPa}]$ は皮膚表面での飽和水蒸気圧， $p_{a}[\mathrm{kPa}]$ は環 境の水蒸気圧, $A_{D u}\left[\mathrm{~m}^{2}\right]$ は各 Segment 表面積である。

皮膚表面から環境までの潜熱伝達率 $h_{e}$ は $i_{c l}$ 係数を用いた表現 とし(13)式で求められる。

$$
h_{e}=L R \cdot i_{c l} /\left(0.155 I_{c l}+\frac{i_{c l}}{h_{c} \cdot f_{c l}}\right)
$$

Stolwijk モデル7/8)では着衣熱抵抗が考慮されていないが，COM ではサーマルマネキン測定による各 Segment 別の着衣熱抵抗 $I_{c l}$ [clo］を用いて考慮することとした。 $h_{c}\left[\mathrm{~W} / \mathrm{m}^{2}{ }^{\circ} \mathrm{C}\right]$ は人体の対流熱 伝達率, $f_{c l}[-]$ は着衣面積比である。 $L R\left[{ }^{\circ} \mathrm{C} / \mathrm{kpa}\right]$ はルイス係数 であり, $L R=16.5^{\circ} \mathrm{C} / \mathrm{kPa}$ である。また, 全身各 Segment について $i_{c l}=0.45$ とする。本モデルでは着衣は顕熱・潜熱抵抗としてのみ取 り扱っており, 熱容量, 吸放湿に関しては考虑していない甥7。

\section{3-7 皮膚表面の顕熱交換}

$Q_{t}[\mathrm{~W}]$ は皮膚表面と環境の対流および放射熱交換であり，(14)式 のように総合熱伝達率を用いた表現とした。 $h_{t}\left[\mathrm{~W} / \mathrm{m}^{2}{ }^{\circ} \mathrm{C}\right]$ は各 Segment の皮虙から環境までの総合熱伝達率， $T_{s k}\left[{ }^{\circ} \mathrm{C}\right]$ は皮膚表面の 温度, $t_{o}\left[{ }^{\circ} \mathrm{C}\right]$ は作用温度である。

$$
Q_{t}=h_{t}\left(T_{s k, u n c}-t_{o}\right) A_{D u}
$$

$h_{t}$ は clo 值を用いると(15)式のように表現される。すなわちその逆 数は, 着衣量 $I_{c l}[\mathrm{clo}]$ と着衣外表面における表面空気層の熱抵抗の 和として表現できる。 $h_{r}\left[\mathrm{~W} / \mathrm{m}^{2}{ }^{\circ} \mathrm{C}\right]$ は線形放射熱伝達率である。

$$
\frac{1}{h_{t}}=0.155 I_{c l}+\frac{1}{\left(h_{c}+h_{r}\right) f_{c l}}
$$

COM の Segment 分割は皮膚温可変型サ一マルマネキン16)にほ ぼ対応しているので， $h_{c} ， h_{r}$ の值には，サーマルマネキンによる測 定值 ${ }^{17)}$ を用いることができる゙8)。本モデルでは, Segment 別測定値 (对流熱伝達率については気流条件毎の測定值)に，(16)～(18)式で示さ れる $\operatorname{Mod}_{c} ， \operatorname{Mod}_{r}$ 係数を乗じて熱伝達率を算出するものとした。 $\operatorname{Mod}_{c}$ は(17)式による值と(18)式による值の大きい方とした。この取り 扱い方法は 7 項においての $65 \mathrm{MN}^{3 / 4)}$ と比較のため同様とした。 $[\mathrm{m} / \mathrm{s}], h_{c, a v e}\left[\mathrm{~W} / \mathrm{m}^{2}{ }^{\circ} \mathrm{C}\right], h_{r, a v e}\left[\mathrm{~W} / \mathrm{m}^{2}{ }^{\circ} \mathrm{C}\right]$ はそれぞれ, 面積重み 付计平均した全身の相対気流速度, 対流熱伝達率の測定值, 線形放 射熱伝達率の測定値である。表 7 に静穞気流下（ $0.13 \mathrm{~m} / \mathrm{s}$ 以下）の $h_{c}$ と $h_{r}$ を示す师9)。なお, 表 7 に示した熱伝達率は立位のものである ため, 本モデルは立位への对応が可能である。ただし, 表 7 の值を 姿勢に従って変更すれば，他の姿勢にも対応可能である。

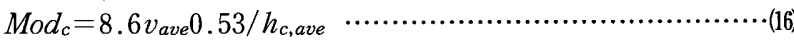

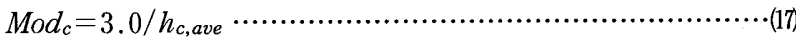

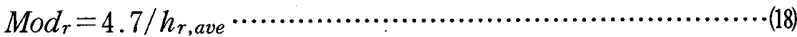

SET*の2node-model ${ }^{2)}$ では, 対流熱伝達率を代謝量の関数とし て, 作業時の相対気流速度増加を考慮しているが, 本モデルでは考

表 7 静穏気流下 $(0.13 \mathrm{~m} / \mathrm{s}$ 以下 $)$ の $h_{c}(i)$ と $h_{r}(i)$

\begin{tabular}{l|r|r}
\hline Segment & $h_{c}\left[\mathrm{~W} / \mathrm{m}^{20} \mathrm{C}\right]$ & $h_{r}\left[\mathrm{~W} / \mathrm{m}^{\circ} \mathrm{C}\right]$ \\
\hline \hline Head & 4.5 & 4.9 \\
\hline Neck & 4.5 & 4.9 \\
\hline Chest & 3.0 & 4.3 \\
\hline Back & 2.9 & 4.1 \\
\hline Pelvis & 2.9 & 4.3 \\
\hline L.Shoulder & 3.6 & 4.5 \\
\hline L.Arm & 3.6 & 4.4 \\
\hline L.Hand & 3.7 & 4.2 \\
\hline R.Shoulder & 3.6 & 4.5 \\
\hline R.Arm & 3.6 & 4.4 \\
\hline R.Hand & 3.7 & 4.2 \\
\hline L.Thigh & 2.8 & 4.8 \\
\hline L.Leg & 2.0 & 5.3 \\
\hline L.Foot & 2.0 & 6.1 \\
\hline R.Thigh & 2.8 & 4.8 \\
\hline R.Leg & 2.0 & 5.3 \\
\hline R.Foot & 2.0 & 6.1 \\
\hline Total & 3.0 & 4.7 \\
\hline
\end{tabular}


慮していない。動作による相対気流速度増加に関しては, 対流熱伝 達率そのものを変更することとした。また, サーマルマネキンの等 価温度 ${ }^{16)}$ を計算に用いることも可能である。この場合は， $h_{t}$ を標準 状態に固定し, 作用温度の代わりに各 Segment 等価温度を代入する ことによって $Q_{t}$ を求める。

\section{4. 制御系}

COM の体温調節の制御式は Stolwijk モデル778)を基本として以 下のように取り扱った。

\section{4-1 センサー信号}

各部のエラーシグナル $\operatorname{Err}\left[{ }^{\circ} \mathrm{C}\right]$ は，(19)式に示す通り，各部の温 度 $T\left[{ }^{\circ} \mathrm{C}\right]$ とセットポイント温度 $T_{\text {set }}\left[{ }^{\circ} \mathrm{C}\right]$ との差, および受容器 の非定常特性の和とした。各部の制御目標温度としての $T_{\text {set }}$ の值は 非常に重要である。本モデルで用いたセットポイント温度および計 算の初期温度である，各部の設定温度を表 8 に示すす10)。

$E r r=\left(T-T_{\text {set }}\right)+R A T E \cdot F$

ここで, RATE [h] は温度受容器の動的感度, $F\left[{ }^{\circ} \mathrm{C} / \mathrm{h}\right]$ は微 小温度変化量である。 $T_{\text {set }}$ と $R A T E$ は制御系の特性であり, 定数と して与えられる゙11)。

温・冷温度受容器に対応して, 各部の Warm シグナル $\left(\mathrm{Wrm}\left[{ }^{\circ} \mathrm{C}\right]\right)$ とCold シグナル $\left(\mathrm{Cld}\left[{ }^{\circ} \mathrm{C}\right]\right)$ を(20)，(21)式で定義する ${ }^{* 12) 。 ~}$

Err が正の值のとき温受容器が動作中とし,

$W r m=E r r$, $C l d=0$

Errが負の值のとき冷受容器が動作中とし,

$C l d=-E r r, \quad W r m=0$ $\cdot(21)$

表 8 各部の設定温度 $\left[{ }^{\circ} \mathrm{C}\right]$

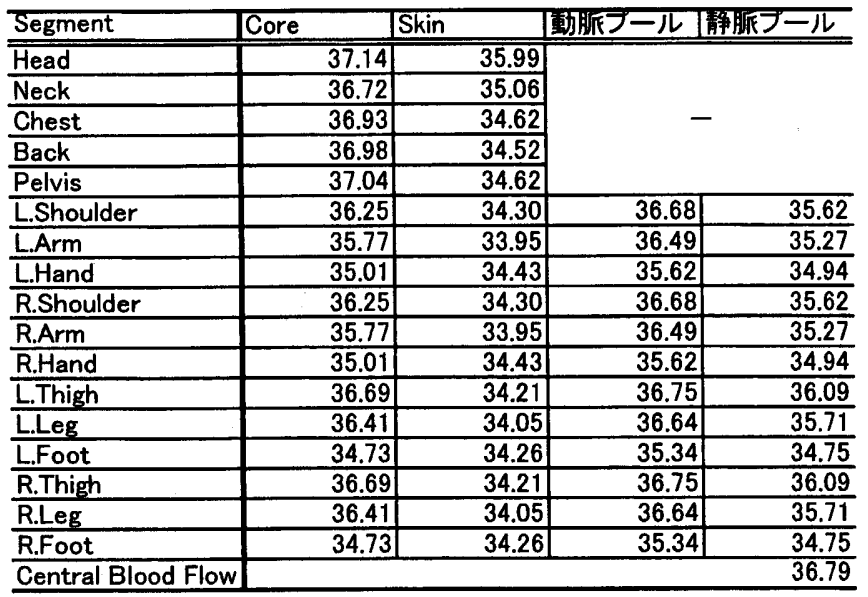

\section{4-2 統合信号}

各 Segmentの Skin からのセンサーシグナルは, 中枢にて統合さ れると考之る。皮膚温受容器からの重み付忛出力 $\left(\operatorname{Wrm}\left[{ }^{\circ} \mathrm{C}\right]\right)$, 皮 膚冷受容器からの重み付け出力 $\left(C l d\left[{ }^{\circ} \mathrm{C}\right]\right)$ は(22), (23)式の上jに示 される。SKINR はSkin からのセンサーシグナルを統合するための Segment 別重み付け係数であり，表 9 に示す。

$$
W r m s=\sum_{\text {各.Segment }}\left(\text { SKINR } \cdot W r m_{s k}\right)
$$

表 9 各部 Skin 層の全身に対する相対比 [-] と各部 Shivf 值 [-]

\begin{tabular}{l|r|r|r|r|r}
\hline Segment & SKINR & SKINS & SKINV & SKINC & Shivf \\
\hline Head & 0.0549 & 0.0640 & 0.1043 & 0.0500 & 0.0339 \\
\hline Neck & 0.0146 & 0.0170 & 0.0277 & 0.0500 & 0.0436 \\
\hline Chest & 0.1492 & 0.1460 & 0.0980 & 0.1500 & 0.2739 \\
\hline Back & 0.1321 & 0.1290 & 0.0860 & 0.1500 & 0.2410 \\
\hline Pelvis & 0.2122 & 0.2060 & 0.1380 & 0.1500 & 0.3875 \\
\hline L.Shoulder & 0.0227 & 0.0510 & 0.0313 & 0.0500 & 0.0024 \\
\hline L.Arm & 0.0117 & 0.0260 & 0.0163 & 0.0500 & 0.0014 \\
\hline L.Hand & 0.0923 & 0.0155 & 0.0605 & 0.3500 & 0.0002 \\
\hline R.Shoulder & 0.0227 & 0.0510 & 0.0313 & 0.0500 & 0.0024 \\
\hline R.Arm & 0.0117 & 0.0260 & 0.0163 & 0.0500 & 0.0014 \\
\hline R.Hand & 0.0923 & 0.0155 & 0.0605 & 0.3500 & 0.0002 \\
\hline L.Thigh & 0.0501 & 0.0730 & 0.0920 & 0.0500 & 0.0039 \\
\hline L.Leg & 0.0251 & 0.0360 & 0.0230 & 0.0500 & 0.0018 \\
\hline L.Foot & 0.0167 & 0.0175 & 0.0500 & 0.3500 & 0.0004 \\
\hline R.Thigh & 0.0501 & 0.0730 & 0.0920 & 0.0500 & 0.0039 \\
\hline R.Leg & 0.0251 & 0.0360 & 0.0230 & 0.0500 & 0.0018 \\
\hline R.Foot & 0.0167 & 0.0175 & 0.0500 & 0.3500 & 0.0004 \\
\hline & & & & &
\end{tabular}

$C l d s=\sum_{\text {\&segment }}\left(\right.$ SKINR $\left.\cdot C l d_{s k}\right)$ (23)

\section{5、体温制御方法}

制御系の式は，制御係数と Head の Core からのセンサーシグナ ルの結果から成る項，制御係数と Skin からの統合シグナルの結果 から成る項，制御係数と Headの Core からのセンサーシグナル・ Skin からの統合シグナルの結果から成る項を待つ。制御方法には, 血管運動（皮膚血管拡張·収縮）, 発汗, 子る之熱産生がある。各体 温制御反応に関する全身に対する相対比は，表 9 に示す值を用いて 計算を行った。また，各体温制御反応の制御係数を表10に示す。以 下に示す各制御式から求饻れる $D L, S T, E_{s w}, M_{\text {shiv }}$ は，負值に なることがあるが，その時は 0 とする。

表10 各体温制御反忘の制御係数

\begin{tabular}{|c|c|c|c|}
\hline & Core $(C)$ & $\operatorname{Skin}(S)$ & Core $\times$ Skin $(P)$ \\
\hline 㖪汗 $(s w)$ & $371.2\left(\mathrm{~W} /{ }^{\circ} \mathrm{C}\right)$ & $33.6\left(\mathrm{~W} /{ }^{\circ} \mathrm{C}\right)$ & $0.0\left(W /{ }^{\circ} \mathrm{C}^{2}\right)$ \\
\hline ふるるえ慗産生(shiv) & $0.0\left(\mathrm{~W} /{ }^{\circ} \mathrm{C}\right)$ & $0.0\left(\mathrm{~W} /{ }^{\circ} \mathrm{C}\right)$ & $24.4\left(W /{ }^{\circ} C^{2}\right)$ \\
\hline 血管払强( & $117.0\left(\mathrm{~L} / \mathrm{h}^{\circ} \mathrm{C}\right)$ & $7.5\left(\mathrm{~L} / \mathrm{h}^{\circ} \mathrm{C}\right)$ & $0.0\left(L / h^{\circ} C^{2}\right)$ \\
\hline 血管収維(st) & $10.8\left(1 /{ }^{\circ} \mathrm{C}\right)$ & $10.8\left(1 /{ }^{\circ} \mathrm{C}\right)$ & $0.0\left(1 /{ }^{\circ} \mathrm{C}^{2}\right)$ \\
\hline
\end{tabular}

\section{5-1 皮有血流量}

各 Segment の皮虐血流量 $V_{s k}[\mathrm{~L} / \mathrm{h}]$ は(24)式で表される。 $D L[\mathrm{~L} /$ h］は血管拡張に関するシグナル， $S T$ [一］は血管収縮に関するシ グナルで各々(25)，(26)式のように表現される。SKINV[-]，SKINC [一] は $D L, S T$ についての各 SegmentのSkin 層の全身に対する 相対比である。また, Err $r_{c r, h e a d}, W r m_{c r, h e a d}, C l d_{c r, \text { head }}$ はそれぞれ Headの Coreにおけるエラーシグナル, Warm シグナル, Cold シグ ナルである。

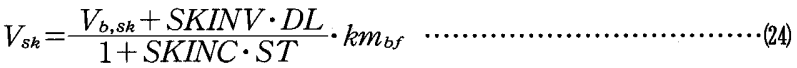

$$
\begin{aligned}
& D L=C d l E r r_{c r, h e a d}+S d l(W r m s-C l d s) \\
& + \text { PdlWrmcr,head Wrms. } \\
& S T=-C s t E r r_{c r, \text { head }}-S s t(W r m s-C l d s) \\
& + \text { PstCld }_{c r, \text { head }} \text { Clds }
\end{aligned}
$$

ここで, $C d l\left[\mathrm{~L} / \mathrm{h} \cdot{ }^{\circ} \mathrm{C}\right], S d l\left[\mathrm{~L} / \mathrm{h} \cdot{ }^{\circ} \mathrm{C}\right], P d l\left[\mathrm{~L} / \mathrm{h} \cdot{ }^{\circ} \mathrm{C}^{2}\right]$ はそれ ぞれ Headの Coreから, Skinから, Headの Core と Skinからの 
血管拡張制御係数, Cst $\left[1 /{ }^{\circ} \mathrm{C}\right]$, Sst $\left[1 /{ }^{\circ} \mathrm{C}\right]$, Pst $\left[1 /{ }^{\circ} \mathrm{C}^{2}\right]$ はそれ ぞれ Headの Core から, Skin から, Headの Core と Skin からの 血管収縮制御係数である。

(24)式の $k m_{b f}[-]$ は皮膚血流量に関するイフェクター動作量と呼 ばれ(27)式で表される。Err ${ }_{s k}\left[{ }^{\circ} \mathrm{C}\right]$ は各 SegmentのSkinにおける工 ラーシグナル， $R T_{b f}\left[{ }^{\circ} \mathrm{C}\right]$ は皮膚血流に関するイフェクター動作量 が 2 となるための必要温度幅である。本論文では, 全身各 Segment について $R T_{b f}=6{ }^{\circ} \mathrm{C}$ とした ${ }^{7) 8) \pm 13) 。 ~}$

$$
k m_{b f}=2.0^{E r r_{s k} / R T_{b s}}
$$

\section{5-2 発汗}

各 Segment の発汗による蒸発熱損失量 $E_{s w}[\mathrm{~W}]$ は，(28)式で示さ れる。SKINS [-] は, 発汗についての各 Segment の Skin 層の全 身に対する相対比である。

$$
\begin{aligned}
E_{s w}= & \left\{C s w E r r_{c r, \text { head }}+S s w(\text { Wrms }-C l d s)\right. \\
& \left.+P s w W r m_{c r, \text { head }} \text { Wrms }\right\} \cdot \operatorname{SKINS} \cdot \mathrm{km}_{s w}
\end{aligned}
$$

ここで, $\operatorname{Cs} w\left[\mathrm{~W} /{ }^{\circ} \mathrm{C}\right], S s w\left[\mathrm{~W} /{ }^{\circ} \mathrm{C}\right], \operatorname{Ps} w\left[\mathrm{~W} /{ }^{\circ} \mathrm{C}^{2}\right]$ はそれぞれ Headの Core から, Skin から, Headの Core と Skin からの発汗制 御係数である。

$k m_{s w}[-]$ は発汗に関するイフェクター動作量であり，(29)式で表 される。Err ${ }_{s k}\left[{ }^{\circ} \mathrm{C}\right]$ は各 Segment の Skin におけるエラーシグナル, $R T_{s w}\left[{ }^{\circ} \mathrm{C}\right]$ は発汗に関するイフェクター動作量が 2 となるための必 要温度幅である。本論文では, 全身各 Segmentについて $R T_{s w}=$ $10^{\circ} \mathrm{C}$ とした ${ }^{7) 8) \notin 13) 。 ~}$

$$
k m_{s w}=2.0^{E r r_{s k} / R T_{s w}}
$$

\section{5-3 ふるええ熱産生}

各 Segment の子るえ熱産生量 $M_{\text {shiv }}$ [W] は(30)式で表される。

$$
M_{\text {shiv }}=\left\{-C_{\text {shivErr }} \text { cr,head }-\operatorname{Sshiv}(\text { Wrms }-C l d s)\right.
$$$$
\left.+ \text { PshivCld }{ }_{c r, \text { head }} \text { Clds }\right\} \cdot \text { Shivf }
$$

ここで, Cshiv $\left[\mathrm{W} /{ }^{\circ} \mathrm{C}\right], \operatorname{Sshiv}\left[\mathrm{W} /{ }^{\circ} \mathrm{C}\right], \operatorname{Pshiv}\left[\mathrm{W} /{ }^{\circ} \mathrm{C}^{2}\right]$ はそれ ぞれ Headの Core から, Skin から, Headの Core と Skin からの ふるえ制御係数である。Shivf [一] はふる之熱産生についての各 SegmentのCore 層の全身に対する相对比であり，表 9 に示す。

\section{COM による SET*の算出}

COM では，各 Segment の皮虐温を面積重み付けした平均皮膚温 $t_{s k}\left[{ }^{\circ} \mathrm{C}\right]$, 全身のぬれ率 $w[-]$, 皮虚表面からの熱損失量 $Q_{s k}[\mathrm{~W} /$ $\mathrm{m}^{2}$ ] を用いて, COMSET $T^{*}\left[{ }^{\circ} \mathrm{C}\right]$ を算出するものとした。その基礎 式は(31)式である。 $P_{s, s k}, P_{s, \text { COMSET }}{ }^{*}[\mathrm{kPa}]$ は，それぞれ $t_{s k}\left[{ }^{\circ} \mathrm{C}\right]$, $\mathrm{COMSET}^{*}\left[{ }^{\circ} \mathrm{C}\right]$ における飽和水蒸気圧である。

$Q_{s k}=h_{t s}\left(t_{s k}-\right.$ COMSET $\left.^{*}\right)+h_{e s} \cdot w\left(P_{s, s k}-0.5 P_{s, \text { COMSET }}{ }^{*}\right) \cdots(31)$ $h_{t s}\left[\mathrm{~W} / \mathrm{m}^{2}{ }^{\circ} \mathrm{C}\right]$ は標準化した総合熱伝達率であり(32)式で示される。

$$
\frac{1}{h_{t s}}=0.155 I_{c l s}+\frac{1}{\left(h_{c s}+h_{r s}\right) f_{c l s}}
$$

ここで, $I_{c l s}[\mathrm{clo}], h_{c s}\left[\mathrm{~W} / \mathrm{m}^{2 \circ} \mathrm{C}\right], h_{r s}\left[\mathrm{~W} / \mathrm{m}^{2}{ }^{\circ} \mathrm{C}\right], f_{c l s}\left[\mathrm{~W} / \mathrm{m}^{2}{ }^{\circ} \mathrm{C}\right]$ は標準化した着衣量, 対流熱伝達率, 線形放射熱伝達率, 着衣面積 比である。I I cls は代謝量により修正され，(33)式で示される。

$$
I_{c l s}=\frac{1.3264}{m e t+0.7383}-0.0953
$$

$h_{c s}$ は代謝量増加による相対気流速度の増加を考慮して(34)式で求 められる。
表11 計算条件

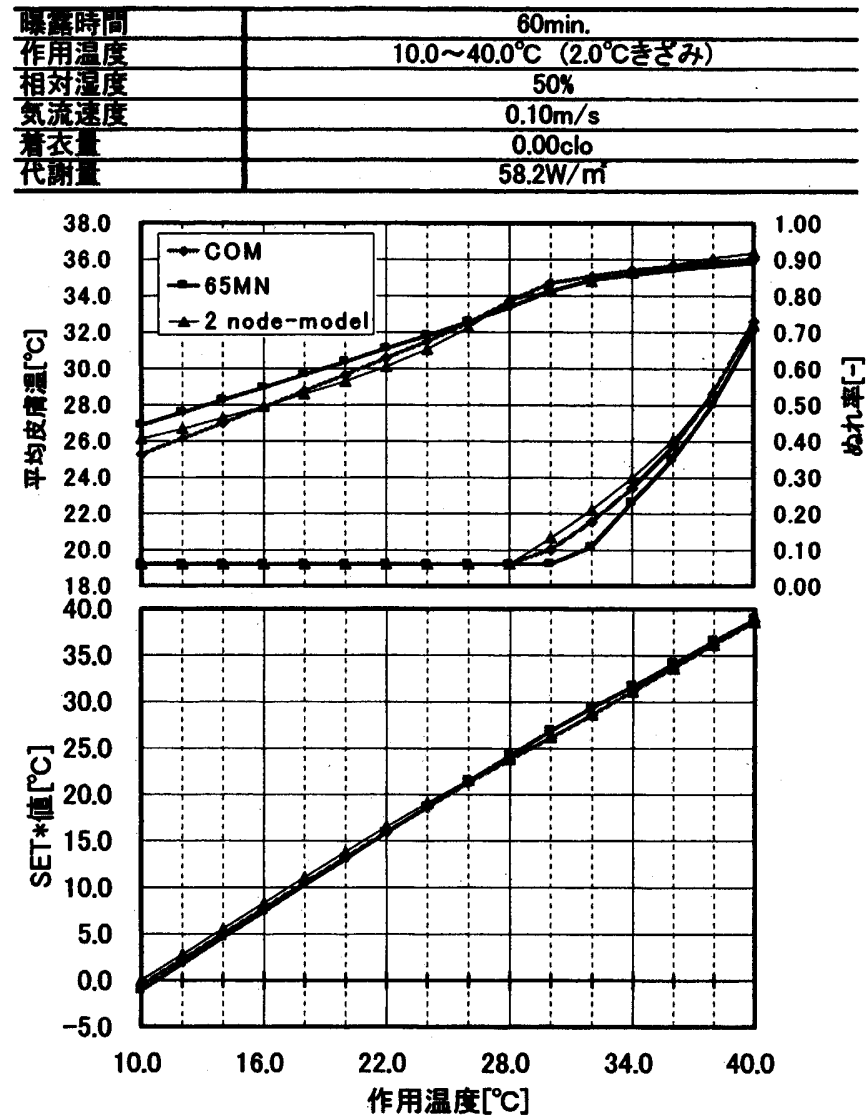

図 5 平均皮膚温・ぬれ率・SET*の比較

$h_{c s}=5.66(m e t-0.85) 0.39$ (34)

$m e t<0.85 \mathrm{met}$ の場合と, (34)式の結果 $h_{c s}<3.0 \mathrm{~W} / \mathrm{m}^{2}{ }^{\circ} \mathrm{C}$ の場合は, $h_{c s}=3.0 \mathrm{~W} / \mathrm{m}^{2} \mathrm{C}$ とした。また, $h_{r s}=4.7 \mathrm{~W} / \mathrm{m}^{2} \mathrm{C}$ とした。また $f_{c l s}$ は (35)式で示される。

$f_{c l s}=1+0.3 I_{c l s}$

また(31)式の $h_{e s}\left[\mathrm{~W} / \mathrm{m}^{2} \cdot \mathrm{kPa}\right]$ は皮虐から環境までの潜熱伝達率で あり，(36)式で示される。

$h_{e s}=i_{m s} \cdot L R \cdot h_{t s}$ $(36)$

ここで $i_{m s}[-]$ は標準 $i_{m}$ 係数であり， $i_{m s}=0.45 て ゙ あ る{ }^{\# 14) 。 ~}$

(31)式（36)式を用いることによって，COM で算出した結果から分 割・分布を考慮した SET*值を計算することが可能となるせ15)。

\section{2node-model との比較}

COM の基本特性や熱伝達率を確認するため, Gagge の2node - model $^{2)}$ 及び $65 \mathrm{MN}^{3 / 4)}$ との比較を行った恬)。2node-model は SET* 算出のための人体熱モデルであり，これまで多くの被験者実験との 比較がなされている。表 $11 に$ 計算条件を示す。図 5 に COM, $65 \mathrm{MN}$ 及び2node-modelによって算出された平均皮虞温, ぬれ率, SET*值 の比較を示す。曝露環境は2node-model との比較のため均一な環境 としているが，血流を含めた Segmentごとの温度分布は2node -model が平均皮膚温として全身で単純化していることとは異なり 詳細に予測している。結果として算出される SET*が良く一致して いることから，均一あるいはそれに近い温熱環境下では全身温冷感 の予測指標ツールとして利用可能と考えられる。 


\section{8. 定常状態シミュレーション \\ 8-1 計算条件}

定常状態での皮膚温分布予測值の精度を検証するため, Werner の被験者実験結果 ${ }^{19)}$ との比較を行った。被験者は, 21 歳 27 歳の男性 6 名, 平均体重 $74.2 \mathrm{~kg}$, 平均身長 $1.806 \mathrm{~m}$ である。実験および計算条 件を表12に示す新17)。被験者は実験の前に60min.標準環境条件に懪露 された。

表12 実験およU゙計算条件

\begin{tabular}{|c|c|c|}
\hline & 泡期经件 & 致积件 \\
\hline 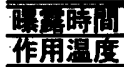 & $\frac{60 \mathrm{~min}}{30^{\circ} \mathrm{C}}$ & $\begin{array}{c}120 \mathrm{~min} .\left(10^{\circ} \mathrm{C} \text { 年件ては90min.) }\right. \\
10,20,30,35,40,45,50^{\circ} \mathrm{C}\end{array}$ \\
\hline 相対湜度 & \multicolumn{2}{|r|}{$40 \%$} \\
\hline 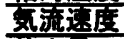 & \multicolumn{2}{|c|}{$0.10 \mathrm{~m} / \mathrm{s}$} \\
\hline 夜 & \multicolumn{2}{|c|}{$0.00 \mathrm{clo}$} \\
\hline 在翮 & \multicolumn{2}{|c|}{$45.3 \mathrm{~W} / \mathrm{m}$} \\
\hline
\end{tabular}

\section{8-2 計算結果・考察}

90min.あるいは120min.の懪露実験終了時の各 Segment 温度につ いて比較した。図 6 に各条件での各 Segment 温度の予測值と対応す るSegment の被験者測定值を共に示す。予測值と測定值は概ね良い 一致を得た。図 $7 に 10^{\circ} \mathrm{C}$ 条件下の皮膚温分布の比較を示すせ18)。皮膚 温分布の傾向を見るために対応する Segment と共に示した。65MN は Armの皮膚温をShoulderより高く算出し，測定值と異なる皮膚 温分布傾向となった。一方, COMにより予測された皮虚温分布は測 定値と似た傾向となった。四肢の末端である Hand および Footに おいては，極めて寒冷な環境のため皮膚血流が極めて少なくなり 65 $\mathrm{MN}$ との皮膚温の差異は小さなものとなった。

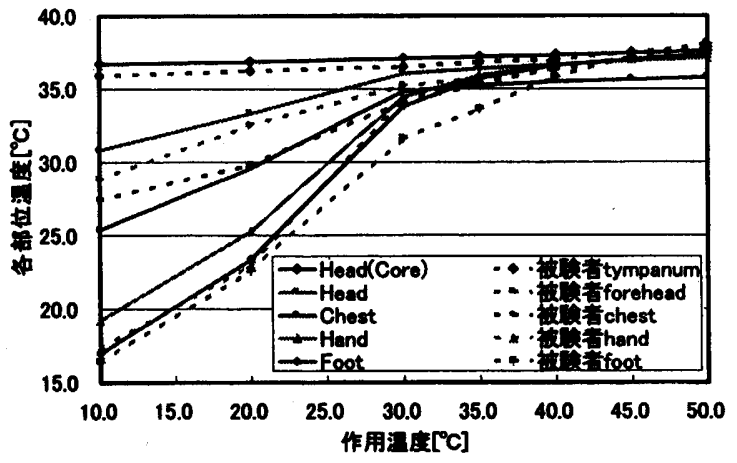

図 6 各温度条件での各 Segment 温度の比較

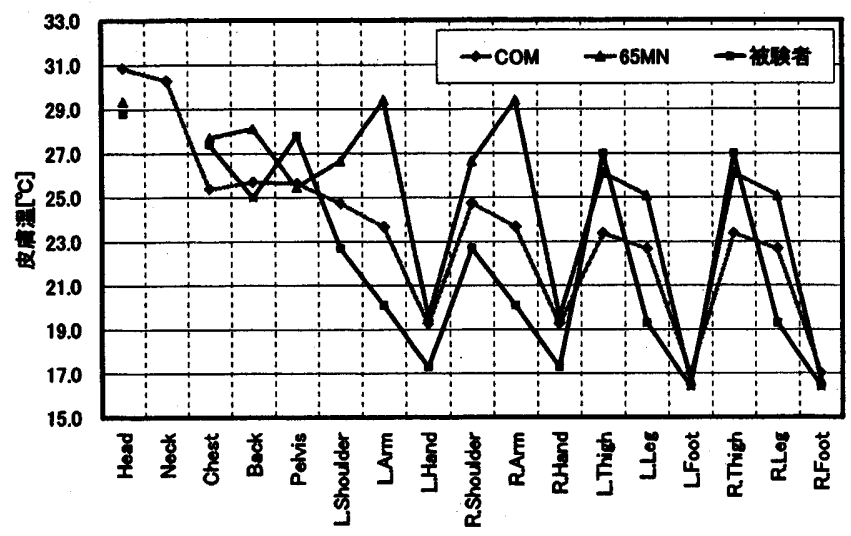

図 $710^{\circ} \mathrm{C}$ 条件下の皮膚温分布の比較
9. 非定常状態シミュレーション

\section{9-1 計算条件}

非定常状態での平均皮膚温予測值の精度を検証するため, Stolwi$\mathrm{jk}$ の被験者実験結果7)との比較を行った。被験者は, 20歳代の男性数 名である。実験および計算条件を表13に示す。被験者は実験の前に $30 \mathrm{~min}$. 標準環境条件に曝露された。

表13 実験および計算条件

\begin{tabular}{|c|c|c|}
\hline & 杣胜织 & 起等件 \\
\hline 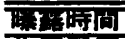 & 30min. & T20min. \\
\hline 作用湿运 & $30^{\circ} \mathrm{C}$ & $48^{\circ} \mathrm{C}$ \\
\hline 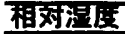 & \multicolumn{2}{|c|}{$50 \%$} \\
\hline xtsited & \multicolumn{2}{|c|}{$0.10 \mathrm{~m} / \mathrm{s}$} \\
\hline 衣依 & \multicolumn{2}{|c|}{$0.00 \mathrm{clo}$} \\
\hline 代最 & \multicolumn{2}{|c|}{$45.3 \mathrm{~W} / \mathrm{m}^{\circ}$} \\
\hline
\end{tabular}

\section{9-2 計算結果・考察}

平均皮膚温の経時変化を比較した。困 8 にCOMによる予測值と 被験者の測定值を示す。ステップチェンジ条件下での予測值と测定 值は概ね良い一致を得た。

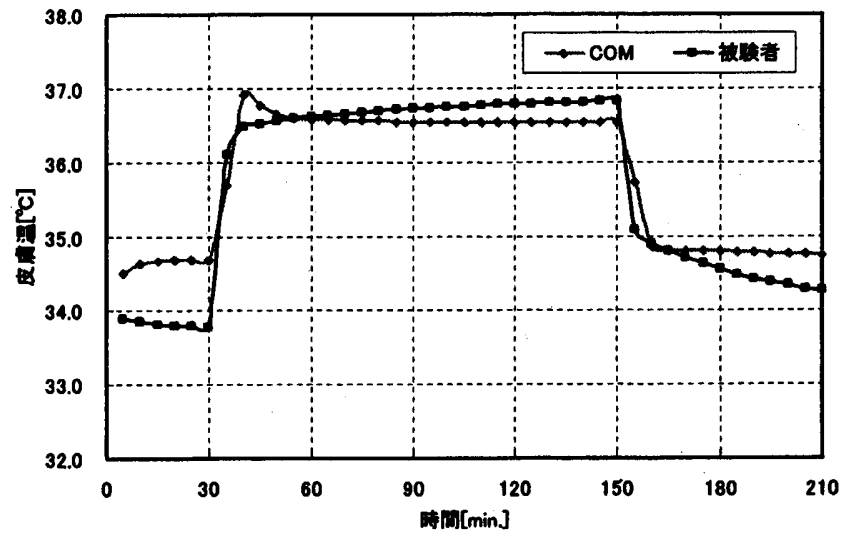

図 8 平均皮膚温の経時変化の比較

10. まとめ

1）詳細な四肢の血流モデルを含めた人体モデルCOMを開発し た。定数・係数を含めた計算モデル・熱平衡式などを示した。さ らに, COMSET*の算出方法を示した。

2) Gagge の2node-model 及び65MN と計算結果の比較を行っ た。平均皮膚温，ぬれ率，SET*值は，2node-model 及び $65 \mathrm{MN}$ に よるものと良い一致が得られ，均一あるいはそれに近い環境下で は COMSET*により温冾感予測が可能であることを確認した。

3 ）定常状態での皮膚温分布子测值の精度を検証するため, Werner の被験者実験結果との比較を行った。各温度条件下で予測された 各 Segment 皮膚温は概ね測定值と一致した。また，65MN と比較 し予測精度の向上を確認した。

4) 非定常状態での平均皮膚温予測值の精度を検証するため, Stolwijk の被験者実験結果との此較を行った。ステップチェンジ 条件下で子測された平均皮膚温の経時変化は概ね測定值と一致し た。 


\section{謝辞}

本研究は, 日本学術振興会科学研究費 (基盤(A)(2), 課題番号 12355022，代表者 田辺新一）により実施したものである。

注釈

注 1) COMの人体のモデルは Stolwijk の 6 円柱モデル778)をもととしてい る。Stolwijkのモデルは Head を表す 1 つの球と Torso, Arms, Hands, Legs, Feet の各 Segment を表す 5 円柱からなる。各 Segment の寸法は以下に示す通りである。Head：半径 $9.88 \mathrm{~cm}$, Torso：半径 $14.70 \mathrm{~cm}$, 長さ $60 \mathrm{~cm}$, Arms : 半径 $5.02 \mathrm{~cm}$, 長さ $112 \mathrm{~cm}$, Hands：半径 $1.49 \mathrm{~cm}$, 長さ $96 \mathrm{~cm}$, Legs: 半径 $6.42 \mathrm{~cm}$, 長さ $160 \mathrm{~cm}$, Feet: 半径 1.57 $\mathrm{cm}$, 長さ $125 \mathrm{~cm}$

注 2 ) 図 4 に示すように, 特に四肢の末端においてはArterial Flow と Venous Flow を直接つなぐ血流経路が考えられる。しかし, 血流と周 囲組織との間の熱交換率および流量制御モデルがこれまでの研究で明 らかとなっていないので, 本モデルではこの血流経路には流量を与えな いものとした。

注 3 ) (1) （5)式の常微分方程式の解法はオイラー法を用いた。(1) 〜 (5)式で用い られた記号については記号一覧を示した。

注 4 ) Segment 間の温度差が小さいため, 隣り合う Segment 間の伝導による 熱移動は血流による熱輸送に比較し小さいと考之られる。そこで, $\mathrm{COM}$ では Segment 間の熱移動は血流によるもののみを考慮した。

注 5 ）本論文では各 Segment の仕事およびふるえがない状態での生理的な 発熱量を基礎的な代謝と定義した。従って，この基礎的な代謝量は生理 学的な基礎代謝量とは異なる。

注 6）呼吸による熱損失については運動生理学の分野で議論されており,未だ 明確になっていない。本研究では計算上ChestのCore 層のみで呼吸に よる熱損失が発生するものとした。

注 7 ）着衣の熱容量については吸放湿に比較すると温冷感への影響が小さい ことが知られている。着衣の吸放湿は非定常を扱う際には重要な要素で あるが, 本研究で計算を行っているような裸体の場合や, 発汗のない㬓 境では影響が小さいと考えられる。着衣を含む人体周辺のモデル化につ いては別途行い，人体のモデルと連成させる予定である。

注 8 ） Neck の熱伝達率は Head と等しいものと仮定した。

注 9 ）気流速度 $0.15 \mathrm{~m} / \mathrm{s}$ の自然対流時にサーマルマネキンの皮虐温と室内温 度との差が $5 \sim 20^{\circ} \mathrm{C}$ の範囲では対流熱伝達率は大きく変化しない。

注10）いずれの体温調節モデルも組み込まない被制御系のモデルを用いて, 作 用温度 $28.8^{\circ} \mathrm{C}$, 相対湿度 $50 \%$, 気流速度 $0.10 \mathrm{~m} / \mathrm{s}$, 着衣量 $0.00 \mathrm{clo}$, 代謝 量1.0met（PMV $= \pm 0$ 条件）での定常計算を行い，得られた各部温度 を設定温度とした。すなわち「生理的温熱中立環境=心理的温熱中立環 境」を仮定した。COM では, 設定温度を解析每に算出可能な構成とし た。

注11）RATEはこれまでの研究では定量的に明らかになっていないので，本

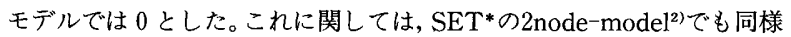
の取り扱いとしている。今後, RATEが定量的に明らかになった時点で 非 0 の数值を与える。

注12）外部物体との接触がある場合には圧力の影響でセンサーシグナルが変 化すると考之られるが, 本研究では圧力の影響に関しては考虑していな い。

注13）(27式や(29)式で表されるイフェクター動作量は, 実験的に求めた量である べきである。しかし, Stolwijk モデルでは一部実験結果を参考にしてい るが, これらの式を仮定している。今後, このイフェクタ一動作量は生 理的な研究が進むにつれ改訂していく必要がある。

注14）(14)式で示される潜熱伝達率 $h_{e}$ の算出では， $i_{c l}$ 係数を用いて定式化を 行ったが,ここでは $i_{m}$ 係数を用いた表現としている。 $i_{m}$ 係数と $i_{c l}$ 保数 の関係は(i)式で表現される。

$$
i_{m}=\left(R_{c l}+R_{a, c l}\right) /\left[\left(R_{c l} / i_{c l}\right)+\left(R_{a, c l} / i_{a}\right)\right]
$$
ここで， $R_{c l}, R_{a, c l}\left[\mathrm{~m}^{2}{ }^{\circ} \mathrm{C} / \mathrm{W}\right]$ はそれぞれ着衣，着衣外表面の熱抵抗 である。 $i_{a}[$ 一] は着衣外表面の空気首の透湿係数であり, 対流熱伝達 率 $h_{c}\left[\mathrm{~W} / \mathrm{m}^{2}{ }^{\circ} \mathrm{C}\right]$ と線形放射熱伝達率 $h_{r}\left[\mathrm{~W} / \mathrm{m}^{2}{ }^{\circ} \mathrm{C}\right]$ を用いて(ii)式で表 される。

$i_{a}=h_{c} /\left(h_{c}+h_{r}\right)$ ...(ii)

注15）不均一放射環境においては，温冷感が特異な反応を示すことが渡邊らに
よって明らかにされている18)他が, COMSET*ではその特幑は考慮して いない。

注16） 2 node-model の計算には，次の係数を用いた。発汗制御係数 $(C s w)=$ $170\left[\mathrm{~g} / \mathrm{m}^{2} \mathrm{hK}\right]$, 血管拡張制御係数 $(C d i l)=200\left[\mathrm{~L} / \mathrm{m}^{2} \mathrm{hK}\right]$ ，血管収縮 制御係数 $($ Str $)=0.5[-]$ 。

注17）実験では被験者はハンモック上に横たわっていた。計算ではモデルの基 礎代謝量 $45.3 \mathrm{~W} / \mathrm{m}^{2}$ 与えた。

注18）被験者の皮膚温測定位置は文献19)に次の上うに表記されている。 Head : forehead, Pelvis：abdomen, leg：calf, 等。温度測定には熱 電対が用いられた。

\section{参考・引用文献}

1) P.O. Fanger: Thermal Comfort, Danish Tech. Press, 1970

2) A.P. Gagge, A.P. Fobelets and L.G. Berglund: A Standard Predictive Index of Human Response to the Thermal Environment, ASHRAE Transactions, Vol. 92, Part 2, pp.709-731, 1986

3）田辺新一，中野淳太，小林弘造：温熱環境評価のための65分割体温調節モ デルに関する研究，日本建築学会計画系論文報告集，第541号（2001年 3 月), pp.9-16, 2001

4) K. Kobayashi, J. Nakano, S. Tanabe: Development of 65-node Thermoregulation Model for Evaluation of Thermal Environment, Proceedings of Healthy Buildings, Vol. 2, pp.563-568, 2000

5）小林弘造, 小川一晃, 田辺新一：人間一快適性シミュレー夕(その $2 \sim 3$ ), 日本建築学会大会学術講演梗概集 (東北), pp.391-394, 2000

6）山本ゆう子，田辺新一，小林弘造，小川一晃：体内温度分布を考虑した数 值体温調節モデルー3DM, 空気調和・衛生工学会学術講演会講演論文集, pp.1221-1224, 2000

7) J.A.J. Stolwijk: A Mathematical Model of Physiological Temperature Regulation in Man, NASA, CR-1855, 1971

8) J.A.J. Stolwijk, J.D. Hardy : Control of Body Temperature, Handbook of Physiology, Section 9, Reaction to Environmental Agents (ed. Douglas), Amer., Physiol. Soc., pp.45-68, 1977

9) C.E. Smith: A Transient, Three-Dimensional Model of the Human Thermal System, KSU, Dissertation, 1993

10）横山真太郎：生体内熱移動現象, 北海道大学図書刊行会, 1993

11）横山真太郎, 角田直人, 富樫貴子, 濱田靖弘, 中村真人, 落籍 澄：部位 別特性を考慮した生体内温度予測プログラムの開発 第 1 報一生体内熱 移動方程式とその解法, 空気調和・衛生工学会論文集, No. 77, pp.1-12, 2000.4

12) R.G. Gordon, R.B. Roemer, S.M. Horvath: A Mathematical Model of the Human temperature Regulatory System-Transient Cold Exposure Response, IEEE Transactions on Biomedical Engineering, Vol. BME23, No. 6, pp.434-444, 1976.11

13) J.W. Mitchell, G.E. Myers: An Analytical Model of the Coutercurrent Heat Exchange Phenomena, Biophysical Journal, Vol. 8, pp. 897-911, 1968

14）片岡拓也, 房田泰治：人体熱モデルを用いた自動車室内温熱環境評価，日 本機械学会論文集（B 編），64卷，628号，pp.331-336，1998.12

15) Chapter 8 Thermal Comfort, 2001 ASHRAE Fundamentals Handbook, pp.8.3-8.4, 2001

16）田辺新一,長谷部ヤエ：皮虐温可変型サーマルマネキンによる室内環境評 価法に関する研究，日本建築学会計画系論文報告集，第448号（1993年 6 月), pp.1-8, 1993

17）市原真希，新藤正文，西村美加，田辺新一：サーマルマネキンを用いた立 位・座位人体各部位の放射・対流熱伝達率の测定，日本建築学会計画系論 文集，第501号（1997年11月)，pp.45-51，1997

18）渡邊慎一, 堀越哲美, 三好結城, 宮本征一：炬烓使用時における人体の熱 的快適性の検討とその温熱効果の定量化, 日本建築学会計画系論文集, 第 497号（1997年 7 月)，pp.47，1997

19) J. Werner, T. Reents: A Contribution to the Topography of Temperature Regulation in Man, European Journal of Applied Physiology, 45, pp.87-94, 1980

（2005年 3 月 10 日原稿受理， 2005 年 9 月 26 日採用決定 $)$ 